\title{
Research on Integration of Red Culture with Ideological and Political Education in Colleges and Universities
}

\author{
Ling Chen \\ Xi'an Peihua University, Xi'an, 710000, China
}

Keywords: Red culture, Ideological and political education, Colleges and universities

\begin{abstract}
As the best textbook to carry out education in colleges and universities, red culture is very important to the cultivation of moral and behavior for contemporary college students. This paper discusses the inheritance, the condensation and the incentive function of the red culture in the ideological and political education of college and university students. Based on the discussion, this paper analyzes the integration of red culture with ideological and political education in colleges and universities, including enriching education content, innovating teaching model and constructing publicity mechanism of red culture to provide some references for the relative researchers.
\end{abstract}

\section{Introduction}

The ideological and political education in colleges and universities is the process of shaping the world outlook, outlook on life and values of college students [1]. It can help contemporary college students establish lofty ideals and beliefs, cultivate elegant moral sentiments, form rational patriotic thoughts, strengthen collectivism and strengthen confidence in building socialism. The ideological and political education in colleges and universities is not merely the educators who speak the truth simply, but also the educational objects who understand how to do it to turn the truth into their own ideology and moral quality. As an excellent educational resource, red culture contains rich material culture and spiritual culture essence. These truths are vivid, intuitive, diverse and powerful, and are generally accepted by contemporary college students. Therefore, red culture can inspire contemporary college students. This can not only enrich the content of the theoretical course of Ideological and political education in Colleges and universities, but also improve the effectiveness of its teaching. The essence of traditional culture is of great significance to the cultivation of cultural confidence in our country. Therefore, the study of red culture's ideological and political education function and its realization path can cultivate our cultural confidence, enhance cultural soft power and promote the construction of socialist culture with Chinese characteristics. As a political culture formed in the new democratic revolution period, red culture reflects the ideals and beliefs of the revolutionary predecessors and national elites, and plays a very important role in guiding, stimulating, condensing and educating in the historical period of the party. In the new era, how to inherit and develop red culture and realize its ideological and political education function is a question to be considered in building the socialism with Chinese characteristics and realizing the great goal of Chinese dream [2].

\section{Important Functions of Red Culture in Ideological and Political Education in Colleges and Universities}

\subsection{Inheritance Function}

The red spirit is a revolutionary spirit that is inherited and developed by means of red culture. It is the scientific understanding of the Communist Party of China combining the basic principles of Marx and the concrete practice of China. The red culture contains a great amount of spirit. It conveys the red spirit to us during the revolutionary war, and these spiritual forces play an important role in the 
war of resistance against Japan, which condenses people, accumulates power and builds up a great revolutionary team. The red spirit inheriting the red culture today is of great importance to the goal of building a well-off society in an all-round way, and the realization of the Chinese dream. The inheritance of red culture in the red spirit to the ideological and political education can greatly enhance the spiritual realm of college students, to improve the effectiveness of education. The red culture has inherited the new democratic revolution from us to a series of scientific theories initiated by the Communist Party of China, such as revolutionary line, policy, guiding ideology and so on. The introduction of a series of scientific theories of the red culture to the ideological and political education in Colleges and universities makes the political and political direction of the contemporary college students clearer and clearer. Red culture, as an excellent culture created by the Chinese nation, has a unique beauty and temperament of red culture and its beauty lies in its inheritance of the revolutionary tradition. The red culture was formed in the period of the new democratic revolution. It is the old generation of revolutionary household blood and life, among which there are no lack of good revolutionary traditions. It is precisely because the red culture has inherited the revolutionary tradition, and the old generation's revolutionary virtues have been inherited and continued. Applying the fine revolutionary tradition inherited from the red culture to the ideological and political education in Colleges and universities, we can strengthen the ideals and beliefs of college students, and enable the red culture to continue, carry forward and carry forward, and contribute to the advanced socialist culture [3].

\subsection{Condensation Function}

The function and Realization of the ideological and political education of red culture can bring together the strength [4]. In every historical period of the Chinese revolution, the Communist Party of China has always been able to arouse the consciousness of the people and bring together the power of the masses of the people. The red culture has brought together the revolutionary and just forces of the people. During the period of socialist construction, it is precisely because of the spirit of the red cultural heritage, China Communist Party can lead the people to gain the success of socialist construction, to develop the socialist economy, create a socialist culture, a solid material foundation and a sound foundation for the new development of the socialist system of reform and opening, to provide construction experience. In the new era of reform and opening, the party leads the people to carry forward the fine tradition of red culture, emancipating the mind, seeking truth from facts and keeping pace with the times, and promoting the development of reform and opening. This series of development cannot do without the people's wisdom and hard work to achieve, cannot do without the masses of red cultural convergence power function. Positive energy is a healthy, healthy and spiritual state that is in line with the mainstream values of society using positive, healthy and stimulating people and things. Positive energy is not only a state of execution or life, but also a way of doing things or living. The red culture has gathered a lot of positive and healthy, stimulating emotion and strength. The emotion and power of the contemporary university students' cohesion, and make efforts to achieve the great Chinese dream. The red culture as the leadership of the Communist Party of China people fought a bloody war with the enemy written in the special culture, it contains abundant spiritual strength, embodies the positive energy rich for the development of the college students.

\subsection{Incentive Function}

The incentive function of red culture means that it can use its own high-quality educational resources to inspire and encourage contemporary college students to be positive, and fully mobilize the enthusiasm, initiative and creativity of college students. Red culture is the excellent educational resources, it contains advanced concepts and rich spiritual strength, to encourage students to forge ahead, work hard, full of vitality, and inspire their patriotic emotion, inspire students' belief, aroused the responsibility of students. Enhancing the incentive function of red culture in Ideological and political education in colleges and universities can further motivate college students to have a clear direction, love their motherland, strengthen their faith and enhance their sense of responsibility, and selflessly dedicate themselves to the cause of socialism. The history of the formation and 
development of red culture is a historical track of red culture that inspires Chinese people's patriotic feelings and national spirit. It is also a miniature of the history of the struggle of the Chinese people led by the Chinese Communists, presenting the feelings of the Communists towards the great motherland. Today, the people of all ethnic groups in China strive to realize the Chinese dream of the great rejuvenation of the Chinese nation. The red culture continues to inspire people's patriotism. The realization of the Chinese nation's great rejuvenation of the Chinese dream requires the common efforts of all the people, which requires the common emotional identity of all the people. The red spirit is the core and essence of the red culture. The spirit of seeking truth from facts is the essence of the different red spirit. The promotion and education of the spirit of seeking truth from facts in the red culture is an important content of spiritual encouragement to the masses of the people. Red culture can be reproduced by red film and television and red literature and art to stimulate the revolutionary people's revolutionary events to stimulate the masses of the people.

\section{Paths of Integration of Red Culture into Ideological and Political Education in Colleges and Universities}

\subsection{Enrich Education Content of Red Culture}

At present, some college students pursue too much material, and the identification of red culture is difficult to achieve a consistent understanding. Strengthening the historical memory of red culture and enhancing the sense of acquisition and identity of red culture is the key to achieve effective integration of red cultural resources to college students' Ideological and political education. History is the best textbook and the best sober. History is the springhead of red culture revolution. By guiding students to seriously study the Communist Party China struggle to explore the history of history, the history of the development, reform and opening up in People's Republic of China, to help college students' perception Chinese Communist Party and people with Chinese blood, sweat, tears and suffering written brilliant, enhance students' understanding of modern Chinese conditions and rules of China social development, enhance the students to enable students to red cultural identity. Take the red culture in the psychological, emotional, theory and practice. In the educational practice, we should innovate the system of Chinese revolutionary history education, strengthen the theoretical education of red culture, and emphasize the propaganda and education of the main melody, including the main melody movie, the main melody and so on. We interspersed the content of red culture into the ideological and political theory class. We can bring red revolutionary deeds, revolutionary spirit, red revolutionary tradition and red heroes into lively teaching, to enhance college students' cognition of red culture. As the main position of cultivating high quality talents, colleges and universities are also an important place to inherit and promote the red culture. Colleges and universities can set up selective courses of red culture according to their own actual conditions, dig deep into the intrinsic value of red culture, make their functions effectively play, and adopt situational teaching methods to stimulate college students' enthusiasm for learning red culture.

\subsection{Innovate Teaching Model of Red Culture}

At present, the object of Ideological and political education of college students is a group of young people after 1990. They have an avant-garde and independent personality, which requires that the content and form of Ideological and political education must conform to their tastes and interests. To get the popularity of post-90s college students, we must enhance their interest and reflect the characteristics of the times. This requires innovation of the content and form of red culture education. Innovation of the content of red culture education. In the new era, red culture emphasizes the value of ordinary people, and highlights the spirit of professionalism, humanities and peaceful cooperation among folk people. These spirits of the times make the red culture more fashionable and advanced. Innovating the way of red culture education. In view of the current young people's interest in red culture is not high, we should take the initiative to cater to the psychological and aesthetic taste of contemporary college students, and adopt micro-blog, WeChat and other new ways to make red 
culture more popular, fashionable and popular. Through many excellent red classics, movies, songs, books, red online games, red micro-blog and other young people's favorite ways, red culture has become a high fashion culture and trend culture. The red culture and red culture network classroom content text and picture processing technology, through digital processing, making pictures, audio and video integration, and information resources to enhance the vividness and interest of red culture, to fully mobilize the students interest in learning, let students immersed in the red culture of learning and feel the red culture. Fourth, a variety of red culture theme activities are carried out with the help of the network platform. For example, the establishment of university student red network game Association and other organizations in the development of colleges and universities, set up a special team in the community of red network game, from the theme selection, game design, game publishing, promotion and other aspects of the feeling of red culture education.

\subsection{Construct Publicity Mechanism of Red Culture}

The construction of long-term mechanism to promote the red culture and red culture propaganda work to put some resources to do regular activities of red culture campus work should also be made of red culture propaganda network platform, such as the establishment of new campus network culture of red color column, the number of public culture. The red culture propaganda work will be long-term and normalized, forming a three-dimensional force of all parties to create a good atmosphere for contemporary college students, and play an important role in their development. To build a cognitive incentive mechanism of red culture, we should decide the way and frequency of the form of encouragement based on the characteristics of the degree of ideological awareness of contemporary college students to form the overall incentive effect of college students' cognition of red culture. To encourage college students to recognize the initiative of red culture, we should combine material incentives with spiritual incentives as scholarships assessment standards and conditions for joining, the incentive for college students' awareness of the red culture, improve their enthusiasm; in the spirit of incentive, can select the red cultural heritage of advanced individuals, such as the honorary title of the red culture model to encourage, enhance cognitive initiative red culture. The red culture department linkage mechanism, to form a reasonable management system, each department needs to work together to form a management system, should pay enough attention to college students, the organization department, propaganda department, Party organizations, community classes, school leaders of the red culture, to achieve a good match. The Red Culture Department linkage mechanism requires all departments should not only be loyal, do a good job, but also mutual coordination and support to other departments on campus cultural construction work red. The various departments of colleges and universities should form a joint force to promote the effective promotion of the red culture function.

\section{Conclusions}

Red culture is an important part of China's advanced culture and represents the direction of advanced culture. Red culture plays an irreplaceable role in Ideological and moral education, ideals and beliefs education, and the education of socialist core values. The integration of red culture into ideological and political education needs the practical support of society and college students in their behaviors.

\section{References}

[1] Chen Deqin. Soviet Area Red Culture Explore Some Values in Local Ideological and Political Education: Take Sanming Soviet Area Red Culture as an Example [J]. Journal of Chengdu University of Technology (Social Sciences), 2017, 25(1): 1-6.

[2] Hao Feifei. A Study of the Path to College Ideological and Political Education in the Perspective of Culture [J]. Theory and Practice of Education, 2017, 37(21): 31-33. 
[3] Yao Ping, Zhang Xiaolin. Exploring Key Link to Integrate the Red Culture into Ideological and Political Education in Colleges and Universities [J]. Journal of Yanlin Vocational \& Technical College, 2017, 16(4): 66-69.

[4] Ren Jiaoli. On Value of Shanxi Red Culture Resources in College Ideological and Political Education [J]. Journal of Taiyuan University, 2014, 15(4): 106-109. 